DOI: https://doi.org/10.32838/2523-4803/70-4-42

УДК 631.162:338.434

\title{
Мальований M.I.
}

доктор економічних наук,

професор кафедри фінансів,

банківської справи та страхування,

Уманський національний університет садівництва

ORCID: https://orcid.org/0000-0002-5541-6463

Ocinoва A.A.

викладач кафедри економіки,

Уманський національний університет садівництва

ORCID: https://orcid.org/0000-0002-5330-3676

Malyovanyi Mykhaylo, Osipova Alla

Uman National University of Horticulture

\section{КРЕДИТНІ АСПЕКТИ ДЕРЖАВНОЇ ПІДТРИМКИ СІЛЬСЬКОГОСПОДАРСЬКОГО ВИРОБНИЦТВА УКРАЇНИ}

\begin{abstract}
Сільськогосподарське виробництво є важливою галуззю економіки України, від ступеня розвитку якої залежить добробут населення краӥни та ї̈ продовольча безпека. I нині до складу механізму державної підтримки розвитку сільськогосподарського виробниитва окремою програмою входить часткова компенсація відсоткової ставки за залученими у національній валюті банківськими кредитами. Проблематика изього дослідження зумовлена наявністю обмеженого досвіду застосування зазначеного механізму в нашій країні. У статті аналізуються показники обсягів кредитування $і$ наданих субсидій уповноваженими банками, щзо беруть участь у реалізащії державної програми пільгового кредитування. У процесі дослідження авторами були позначені як основні проблеми реалізації механізму пільгового кредитування сільськогосподарського виробництва Украӥни, так і позитивні підсумки його вдосконалення. Зроблено висновок про високу потребу господарюючих суб'єктів сільського господарства в кредитних ресурсах і необхідності їх підтримки з боку держави.

Ключові слова: сільськогосподарське виробництво, банківське кредитування, відсоткова ставка, державна підтримка, ефективність.
\end{abstract}

Постановка проблеми. Ключовим чинником динамічного розвитку сільськогосподарського виробництва та посилення конкуренції на аграрному ринку є зростання інвестиційної активності сільськогосподарських товаровиробників, якого можна досягти за наявності ефективних кредитних продуктів і стабільної системи державної підтримки сектору цільового банківського кредитування. А тому гострий дефіцит коштів державного бюджету на відшкодування частини витрат по сплаті відсотків за кредитами негативно позначається на інвестиційному кліматі у вітчизняному сільськогосподарському виробництві.

Сільськогосподарський сектор - один 3 найбільш кредитомістких серед усіх сфер діяльності національної економіки. Це, зокрема, пов'язано з сезонним розривом між вкладенням і надходженням коштів, безперервністю процесів відтворення, значною потребою в обігових засобах. Відтак вагомою складовою державної підтримки сільськогосподарських виробників у західних країнах $є$ активно використовуване пільгове кредитування, суть якого полягає в тому, що відсоток за кредит встановлюється на рівні покриття витрат виробником і його можливості забезпечити певний приріст капіталу.
Аналіз останніх досліджень і публікацій. Особливості вдосконалення механізму кредитування та державного регулювання у сфері сільського господарства досліджуються у працях багатьох вітчизняних науковців і практиків. 3-поміж них слід виділити вагомі напрацювання таких учених, як М. Дем'яненко, Ю. Лупенко, О. Непочатенко, П. Саблук та інші, в яких широко висвітлено питання сутності та специфіки кредитних відносин в аграрній галузі [2; 9; 11].

Зокрема, Ю. Лупенко відзначає, що «теоретично банки налаштовані кредитувати сільське господарство, але на практиці кредитування фермерів відбувається повільно, потреби агробізнесу у фінансових ресурсах задовольняються лише почасти. Що стосується малих і середніх сільгоспвиробників, вони значно обмежені в доступі до фінансування» [9].

О. Непочатенко, П. Бечко, А. Корнега вказують, що «при кредитуванні аграріїв для комерційних банків існує низка важелів, що сприяють мінімізації кредитних ризиків. Найбільш істотним є розвиток кредитних бюро, моніторинг банками фінансової та господарської діяльності аграріїв» [11]. 
Однак нині подолання існуючих перешкод щодо поліпшення та розширення фінансово-кредитного забезпечення сільськогосподарських товаровиробників потребує комплексного розв'язання і якісно нового підходу.

Формулювання цілей статті. Мета статті - провести аналіз змін заходів фінансової підтримки шляхом здешевлення кредитів для сільського господарства України.

Виклад основного матеріалу. Більшість економічно розвинених країн дотримуються традицій провадження активної державної підтримки сільськогосподарського виробництва. Їхньою характерною особливістю є специфікація методів державного регулювання, що залежать від рівня розвитку сільського господарства та загальнонаціональних пріоритетів. Відтак сучасна аграрна політика розвинених держав передбачає трансформацію взаємозв'язків між державним і ринковим регулюванням, прямими та непрямими методами підтримки сільського господарства 3 акцентом на останніх, що сприяють підвищенню результативності та конкурентоспроможності галузі, раціональному використанню наявних ресурсів, збалансованості кон'юнктури ринку. Загалом же відносне, а іноді й абсолютне скорочення державних витрат на фінансування сільськогосподарського виробництва в даний час зумовлено підвищенням ефективності аграрної політики в цілому в умовах конкуренції за світове лідерство.

На високу вартість кредитних ресурсів впливають такі фактори: відсутність у більшості сільськогоспо- дарських підприємств стійких довгострокових пасивів і ліквідної застави, тоді як вітчизняні банківські установи вимагають заставну гарантію, що в кілька разів перевищує суму самої позики; складність прогнозування фінансових результатів діяльності сільськогосподарських товаровиробників через їх залежність від природно-кліматичних умов і різких коливань цінової кон'юнктури; неопрацьовані критерії і методики оцінювання кредитоспроможності позичальника з урахуванням специфіки галузі.

Нині кредитна підтримка сільськогосподарських виробників шляхом здешевлення кредитів прописана у відповідних державних програмах. Однак розподіл сум за регіонами традиційно широко варіюється (рис. 1).

Варто відзначити, що питома вага аграрного сектору у ВВП України сягає майже 17\%, тоді як у портфелі банківського кредитування у 2015-2017 рр. займає лише 6-7\%. Разом з тим спостерігається динаміка зростання обсягів кредитування сільськогосподарських підприємств у 2016-2019 рр. Загальна сума виданих кредитів сільськогосподарським підприємствам зросла у 2018 р. на 27,51 млрд грн порівняно з 2013 р., а відсоткова ставка за користування кредитними коштами впродовж 2013-2018 рр. зросла у 1,24 раза: з 14,3\% у 2013 р. до 17,7\% у 2018 р. [16].

Звертаючись до зарубіжного досвіду державної підтримки через кредитування, варто зосередити увагу на канадській моделі державної підтримки працівників сільського господарства. В основі їі провадження - політика пільгового кредитування, яку країна використовує

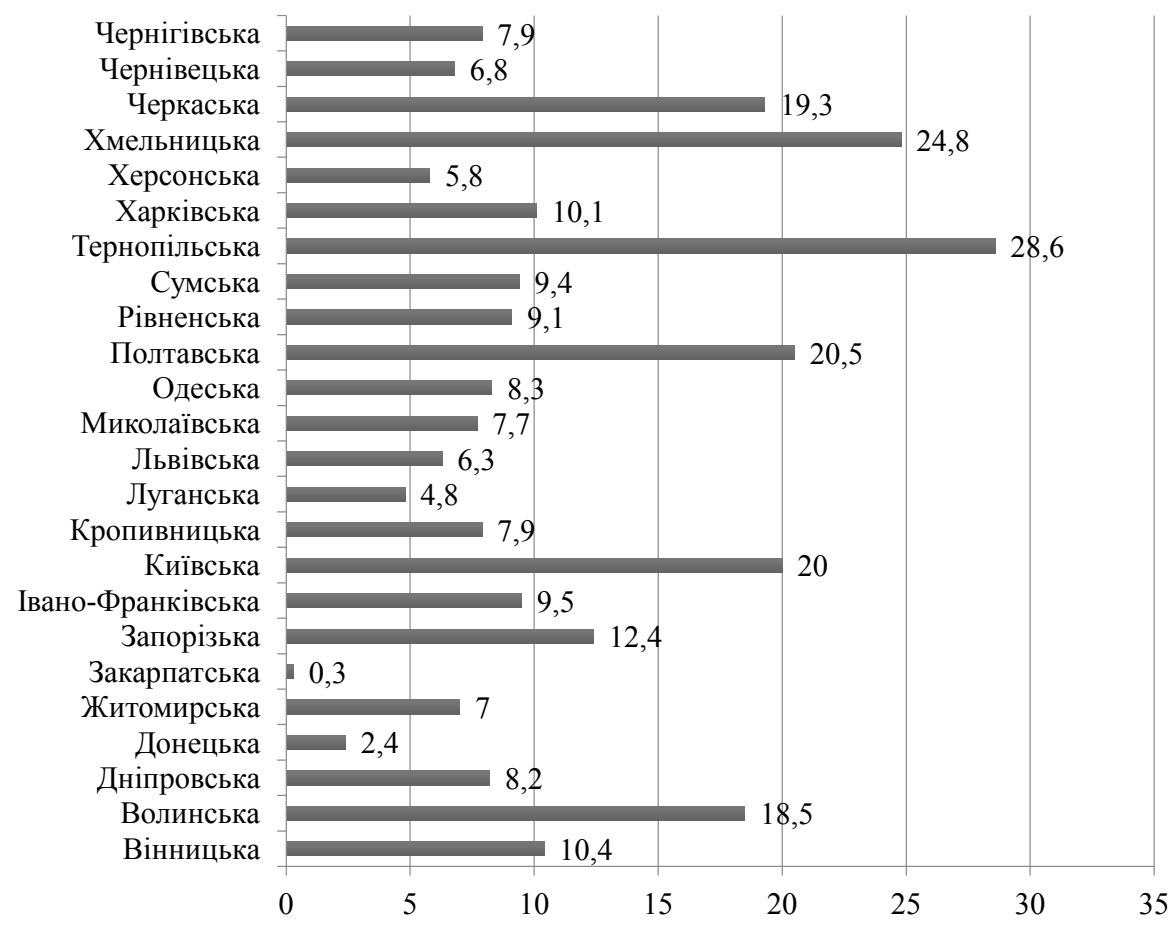

Рис. 1. Обсяги наданої у 2018 р. державної підтримки за програмою 2801030 «Фінансова підтримка АПК» здешевлення кредитів за областями України, млн грн

Джерело: побудовано за даними [7] 
з 1959 р. Федеральний кредитний акт 1959 р. та створений на його основі фонд «Farm credit corporation» зосередили вагому частку коштів та надали можливість сільськогосподарським виробникам брати довгострокові кредити на пільгових умовах. Спрощений доступ до коштів сприяв суттєвому підвищенню рівня інноваційного техніко-технологічного забезпечення фермерських господарств та ефективності їхнього функціонування, що дало змогу Канаді вийти до когорти світових лідерів експорту сільськогосподарської продукції. Водночас недоліком канадської моделі підтримки сільського господарства є досить тривалий період (50 років) очікування ефективних результатів від товаровиробників і постійно зростаюча заборгованість підприємців перед державними кредиторами (банками) [1].

Повчальною для України є модель підтримки, що використовується в аграрній політиці Нідерландів, де активізують цю сферу виробництва шляхом звертання значної уваги на проведення наукових досліджень у галузях сільського господарства. Напрями проведення наукових досліджень, використання їх результатів та впровадження у виробництво координують спеціальні органи, що одержують державне фінансування та контролюються урядом. Держава через ці органи у 2015 р. профінансувала $60 \%$ усіх наукових розробок країни. I така модель державної підтримки наукових досліджень не лише сприяє запровадженню інноваційних технологій у галузях рослинництва та тваринництва, а й підвищенню економічної ефективності функціонування сільського господарства $[18$, с. 52].

Зважаючи на окреслені вище моменти зарубіжного досвіду щодо підтримки сільськогосподарського виробництва на державному рівні, окремої уваги заслуговують кредити інвестиційного характеру на реконструкцію та впровадження нових технологій. Як варіант вирішення даної проблеми - поряд 3 комерційними банками, слід створювати кооперативні банки у вигляді споживчих кредитних. Кредити своїм пайовикам кооперативний банк може видавати за мінімально можливими відсотковими ставками, пов'язуючи та регулюючи процентні ставки від конкретних заходів.

Водночас слід зауважити, що сільськогосподарська сфера виробництва все ж користується високим попитом серед вітчизняних банків. Однак сільськогосподарських товаровиробників не приваблюють відсоткові ставки, що іноді сягають понад $20 \%$ річних. А потреби сільськогосподарських підприємств у фінансовому забезпечені, не зважаючи на готовність банків часто неможливо задовольнити через високі ризики та вартість кредитування. У таких умовах сільськогосподарським підприємствам важко конкурувати не лише на зовнішніх ринках, а й на внутрішньому. Що ж до малих та середніх сільськогосподарських товаровиробників, то складна ситуація у їх кредитному забезпеченні зумовлена відсутністю належного майна для надання очікуваної банком застави.

Згідно із Законом України «Про внесення змін до деяких законодавчих актів України щодо обігу земель сільськогосподарського призначення» 31 липня 2021 р. в Україні відкривається ринок землі. А отже саме земля може бути заставним забезпеченням за кредитом. 3 іншої сторони, існує недовіра кредитора до позичальника. Комерційні банки працюють задля прибутку, але у випадку аграрного кредитування ризикують не лише недоотримати від сільськогосподарського підприємства відсотки за користування кредитом, а й саме тіло кредиту. Виходячи з таких умов, банки надають перевагу кредитуванню великих сільськогосподарських підприємств.

Загалом до ризиків, що виникають у процесі кредитування, відносять: підвищену нестійкість фінансового стану підприємств сільськогосподарської сфери виробництва; невідповідність довгострокових запитів підприємств короткостроковості наявних у банків ресурсів; сезонні особливості сільськогосподарського виробництва, його залежність від природно-кліматичних умов; труднощі, пов'язані з реалізацією продукції; відсутність у позичальників ліквідного забезпечення кредитів; низьку прибутковість операцій 3 кредитування сільськогосподарського виробництва; недостатню правову та нормативну базу кредитування сільського господарства [14].

Крім того, фермери ризикують недоотримати відшкодування частини відсоткової ставки за позикою зі сторони держави. Тож оптимальні умови кредитування банк пропонує сільськогосподарським підприємствам виключно після проведеної оцінки кредитоспроможності позичальника та ризиків кредитування (табл. 1).

Згідно прогнозів банків, кредитний ризик $(62,5 \%)$, ризик ліквідності $(66,7 \%)$ операційний ризик $(50,0 \%)$ збільшиться несуттєво на кінець II кварталу 2020 р., а процентний ризик не зміниться (50,0\% відповідей).

Таким чином, фермер для отримання кредиту має запевнити банк у своїй кредитоспроможності. Водночас банківська діяльність залежить і від інших фак-

Таблиця 1

Прогноз банків щодо зміни рівня ризиків на кінець ІІ кварталу 2020 р., \% відповідей

\begin{tabular}{|l|c|c|c|c|c|}
\hline & $\begin{array}{c}\text { 3меншиться } \\
\text { суттєво }\end{array}$ & $\begin{array}{c}\text { Зменшиться } \\
\text { несуттєво }\end{array}$ & Не зміниться & $\begin{array}{c}\text { 3більшиться } \\
\text { несуттсво }\end{array}$ & $\begin{array}{c}\text { 3більшиться } \\
\text { суттвво }\end{array}$ \\
\hline Кредитний ризик & $4,2 \%$ & $0,0 \%$ & $8,3 \%$ & $62,5 \%$ & $25,0 \%$ \\
\hline Процентний ризик & $0,0 \%$ & $4,2 \%$ & $50,0 \%$ & $37,5 \%$ & $8,3 \%$ \\
\hline Валютний ризик & $0,0 \%$ & $0,0 \%$ & $45,8 \%$ & $45,8 \%$ & $8,3 \%$ \\
\hline Ризик ліквідності & $0,0 \%$ & $4,2 \%$ & $25,0 \%$ & $66,7 \%$ & $4,2 \%$ \\
\hline Операційний ризик & $0,0 \%$ & $0,0 \%$ & $41,7 \%$ & $50,0 \%$ & $8,3 \%$ \\
\hline
\end{tabular}

Джерело: складено за даними [12] 
торів: законодавчого впливу, поведінки контрагентів, загальної економічної ситуації тощо. А вартість фінансування в гривні залежить від ціни ресурсів, за якою банки залучають кошти на міжбанківському ринку для подальшого кредитування сільськогосподарського виробництва. Тобто при зниженні вартості залучених ресурсів кредитні відсоткові ставки одночасно будуть демонструвати аналогічну тенденцію [9].

Водночас, за даними опитування НБУ, частка банкірів, які очікують погіршення стану фінансового сектору в наступні півроку, зросла 3 4\% (у листопаді 2019 р.) до 71\% (у травні 2020 р.). Серед найбільших названих респондентами ризиків - корупція, діяльність правоохоронних органів і судової системи; рівень економічної активності; динаміка світових цін на сировинні товари; шахрайство та кібернетичні загрози; політична ситуація в Україні [6]

Таким чином, можемо стверджувати, що від сприятливої економічної ситуації в країні залежить доступність і термін кредитування комерційними банками сільськогосподарських товаровиробників.

Однак варто також констатувати, що в сучасних умовах дотаційна бюджетна підтримка сільськогосподарського виробництва потребує впровадження оновленого, дієвого в сучасних кризових умовах, механізму. 3 даної позиції важливим $є$ дотримання певних вимог: збереження посівних площ і поголів'я тварин на існуючому рівні та збільшення цих показників; виконання договірних зобов'язань поставок продукції у продовольчі фонди; здійснення інвестицій у виробництво, погашення заборгованості тощо. На думку більшості науковців, сільськогосподарські підприємства можуть виконувати або не виконувати ці вимоги, але у разі невиконання повинні позбавлятися фінансової бюджетної допомоги [14].

Зважаючи на окреслені вище моменти, саме пільгове кредитування може стати важливим методом стимулювання інноваційної діяльності сільгоспвиробників. Проте слід зауважити, що станом на 01.01.2017 р. в Україні банківську ліцензію на здійснення операцій мали 84 комерційні банки, чотири банки виключеного 3 реєстру, оскільки вони ліквідуються. За останні вісім років кількість банківських установ, що мають банківську ліцензію скоротилась на $8,76 \%$. 3 реєстру в період 2010-2017 рр. було виключено 41 установу [5].
На динаміку кредитування сільськогосподарських товаровиробників суттєво вливають фінансові результати діяльності підприємств для підтвердження їх кредитоспроможності. На кінець 2018 р. в Україні було зареєстровано 49208 підприємств, які здійснюють сільськогосподарську діяльність (з них 33164 фермерських господарств). Протягом 2010-2018 років більш ніж вдвічі зменшилася частка збиткових підприємств: 30,4\% у 2010 р. та 13,3\% у 2018 р. Водночас слід відзначити зростання кількості підприємств, що одержали чистий прибуток: з 69,6\% у 2010 р. до 86,7\% у 2018 р. (табл. 2).

У 2018 р. індекс сільськогосподарської продукції становив 108,1\% до рівня попереднього року. Зокрема, у цьому році було вирощено сільськогосподарської продукції на суму 269408, 1 млн грн, що на майже на $80 \%$ більше порівняно з 2000 р. [15].

Водночас загальний рівень фондоозброєності у сільському господарстві залишається на низькому рівні. За даними Продовольчої та сільськогосподарської організації ООН, валове накопичення основного капіталу на 1 га сільськогосподарських угідь в країні більш ніж у 4 рази менше, ніж в середньому по 162 країнах з бази організації. За рівнем державної підтримки сільськогосподарських товаровиробників Україна за даними організації посідає 58 ренкінгове місце 3 66 країн з обсягом витрат у 23,36 дол США на 1 га, що у 5 разів менше за середньосвітовий рівень [17].

3 метою подолання кредитних обмежень сільськогосподарських товаровиробників у 2000 р. в Україні була впроваджена система пільгового кредитування АПК, згідно з якою здешевлення кредитів здійснюється у режимі кредитної субсидії та полягає у субсидуванні частини плати (процентів) за використання кредитів, наданих банками у національній та іноземній валютах. Компенсація надається за кредитами, залученими для покриття виробничих витрат, пов'язаних із закупівлею паливно-мастильних матеріалів, насіння, мінеральних добрив, засобів захисту рослин, кормів, ветеринарних препаратів, молодняку сільськогосподарських тварин та птиці, обладнання для тваринницьких ферм i комплексів тощо [10]. Дана система функціонувала до 2013 року, а от протягом 2013 та 2014 рр. пільгові кредити не надавались. Водночас Законом України «Про

Таблиця 2

Фінансові результати діяльності підприсмств сільськогосподарської галузі, млн грн

\begin{tabular}{|c|c|c|c|c|c|c|c|}
\hline \multirow[b]{2}{*}{ Рік } & \multirow{2}{*}{$\begin{array}{c}\text { Чистий } \\
\text { прибуток } \\
\text { (збиток) }\end{array}$} & \multicolumn{2}{|c|}{$\begin{array}{c}\text { Підприємства, які одержали } \\
\text { чистий прибуток }\end{array}$} & \multicolumn{2}{|c|}{$\begin{array}{c}\text { Підприсмства, які одержали } \\
\text { чистий збиток }\end{array}$} & \multicolumn{2}{|c|}{$\begin{array}{c}\text { Рівень рентабельності } \\
\text { (збитковості), } \%\end{array}$} \\
\hline & & $\begin{array}{c}\text { у \% до } \\
\text { загальної } \\
\text { кількості }\end{array}$ & $\begin{array}{l}\text { фінансовий } \\
\text { результат }\end{array}$ & $\begin{array}{c}\text { у \% до } \\
\text { загальної } \\
\text { кількості }\end{array}$ & $\begin{array}{l}\text { фінансовий } \\
\text { результат }\end{array}$ & $\begin{array}{c}\text { усісї } \\
\text { діяльності }\end{array}$ & $\begin{array}{l}\text { операційної } \\
\text { діяльності }\end{array}$ \\
\hline 2010 & 17253,6 & 69,6 & 22094,9 & 30,4 & 4841,3 & 17,5 & 24,5 \\
\hline 2014 & 21413,4 & 84,7 & 51668,0 & 15,3 & 30254,6 & 9,3 & 21,4 \\
\hline 2015 & 101912,2 & 88,9 & 127525,5 & 11,1 & 25613,3 & 30,4 & 43,0 \\
\hline 2016 & 89816,3 & 88,4 & 102496,1 & 11,6 & 12679,8 & 25,6 & 33,6 \\
\hline 2017 & 68276,8 & 86,7 & 88676,3 & 13,3 & 20399,5 & 16,5 & 23,2 \\
\hline 2018 & 66878,1 & 86,7 & 93135,1 & 13,3 & 26257,0 & 13,5 & 18,5 \\
\hline
\end{tabular}


Державний бюджет на 2015 р.» і в наступних нормативних актах до 2019 р. було передбачено кошти для фінансової підтримки заходів у сфері АПК шляхом здешевлення кредитів: у 2019 р. - 127,2 млн грн, що вдвічі більше, ніж в 2018 р. (266,0 млн грн), однак майже втричі менше, ніж у 2015 р. (300 млн грн) [20].

Міністерством розвитку економіки, торгівлі та сільського господарства України надано кредитів за бюджетною програмою «Надання кредитів фермерським господарствам» у сумі 223 млн грн, у тому числі за загальним фондом - 190,7 млн грн, за спеціальним фондом - 32,3 млн гривень. За рахунок використаних коштів було надано кредити 588 фермерським господарствам, зокрема 494 фермерським господарствам за рахунок коштів загального фонду та 94 - за рахунок коштів спеціального фонду. Середній розмір кредиту на одне господарство за загальним фондом становить 0,4 млн грн, за спеціальним фондом 0,3 млн гривень. Кредитні кошти були спрямовані на придбання техніки й обладнання; поновлення обігових коштів (у т.ч. i для придбання маточного поголів'я сільськогосподарських тварин (телиць, нетелей, корів, свиноматок, ярок, вівцематок, кізочок та козоматок) та проведення оцінки відповідності виробництва органічної продукції (сировини); виробництво та переробку сільськогосподарської продукції; будівництво та реконструкцію виробничих і невиробничих приміщень; закладання багаторічних насаджень.

Також на 25\% збільшилося фінансування програми підтримки розвитку хмелярства, закладки молодих садів, виноградників і ягідників - до 400 млн грн (13,94 млн дол США). На програму фінансової під- тримки сільгосптоваровиробників у 2019 р. було заплановано виділити 881,8 млн грн (29,7 млн дол США), що на 7\% менше, ніж в 2018 р. Ця підтримка здійснювалася за такими напрямами: бюджетна дотація для розвитку сільськогосподарських товаровиробників і стимулювання виробництва сільськогосподарської продукції, що встановлена ст. 161 Закону №1877-IV від 24 червня 2004 р. «Про державну підтримку сільського господарства України»; часткова компенсація вартості придбання сільськогосподарської техніки та обладнання вітчизняного виробництва. У 2019 р. додалася часткова компенсація вартості закуплених у вітчизняних виробників спеціальних вагонів для перевезення зерна, а також обладнання для виробництва біоетанолу й електроенергії з біомаси (табл. 3).

Нині в Україні діють 38 уповноважених банків, через які реалізується програма державної підтримки сільгоспвиробників [3].

У 2020 р., відповідно до постанови КМУ № 106 «Про внесення змін до Порядку використання коштів, передбачених у державному бюджеті для надання фінансової підтримки розвитку фермерських господарств», удосконалено механізм державної підтримки кооперативам i визначено додаткові напрями підтримки фермерським господарствам [19].

Загалом у 2020 р. на фінансову підтримку заходів у сфері сільськогосподарського виробництва шляхом здешевлення кредитів передбачено 1,2 млрд грн. Компенсації підлягають відсоткові ставки за короткостроковими кредитами, залученими для покриття виробничих витрат і середньо- та довгострокові кредити для придбання основних засобів сільськогосподарського

Таблиця 3

Підтримка аграрного сектору в розрізі банків, млн грн [3]

\begin{tabular}{|c|c|c|c|c|c|c|}
\hline Програма підтримки розвитку АПК & 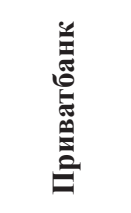 & 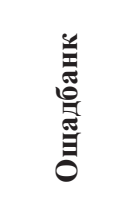 & 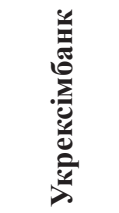 & 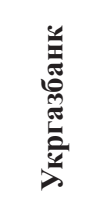 & 具 & فํ. \\
\hline Підтримка розвитку фермерських господарств & 78,096 & 33,107 & 5,250 & 7,570 & - & 124,023 \\
\hline $\begin{array}{l}\text { Часткова компенсація вартості насіння } \\
\text { вітчизняної селекції }\end{array}$ & 4,902 & 1,090 & 0,060 & 0,374 & - & 6,425 \\
\hline $\begin{array}{l}\text { Часткова компенсація витрат, пов'язаних } 3 \\
\text { наданими с/г дорадчими послугами }\end{array}$ & 0,155 & - & - & - & - & 0,204 \\
\hline $\begin{array}{l}\text { Часткова компенсація вартості с/г техніки та } \\
\text { обладнання вітчизняного виробництва }\end{array}$ & 69,113 & 28,647 & 4,478 & 6,700 & - & 108,938 \\
\hline $\begin{array}{l}\text { Часткова компенсація відсоткової ставки за } \\
\text { залученими у національній валюті кредитами, } \\
\text { наданими державними банками }\end{array}$ & 3,926 & 3,322 & 0,712 & 0,497 & - & 8,457 \\
\hline Державна підтримка галузі тваринництва & - & - & 0,179 & 3,399 & 63,096 & 66,674 \\
\hline $\begin{array}{l}\text { Часткова компенсація відсоткової ставки за } \\
\text { банківськими кредитами }\end{array}$ & - & - & 0,179 & 3,399 & 0,170 & 3,748 \\
\hline $\begin{array}{l}\text { Часткова компенсація вартості будівництва та } \\
\text { реконструкції об’єктів, профінансованих за } \\
\text { рахунок банківських кредитів }\end{array}$ & - & - & - & - & 62,926 & 62,926 \\
\hline $\begin{array}{l}\text { Фінансова підтримка с/г товаровиробників: } \\
\text { здешевлення с/г техніки та обладнання }\end{array}$ & 380,252 & 351,306 & 103,421 & 76,933 & 1,028 & 912,90 \\
\hline Всього & 458,348 & 384,413 & 108,850 & 87,902 & 64,124 & 1103,637 \\
\hline
\end{tabular}


виробництва, здійснення витрат, пов'язаних з будівництвом і реконструкцією виробничих об'єктів сільськогосподарського призначення. Для прозорості й оптимізації програми передбачено обмеження щодо суми компенсації до 5 млн грн на одного суб'єкта 3 річним оборотом до 20 млн грн та до 15 млн грн на суб'єкта в тваринництві [13].

Наведені тенденції засвідчують зацікавленість держави у підтримці сільськогосподарської сфери виробництва, однак орієнтація йде переважно на великих, а 3 деяких пір і на середніх (фермерські господарства) виробників. Хоча надзвичайно перспективним сегментом у цьому виді діяльності є малі (особисті, селянські) господарства, які нині як суб'єкти фінансової допомоги від держави не розглядаються.

Висновки. Нині політика фінансування і кредитування аграрного сектору економіки України повинна сприяти підтримці курсу імпортозаміщення та стимулювання просування вітчизняної сільськогосподарської продукції в ринковій і роздрібній торгівлі.

Тому для формування надійної і доступної системи фінансово-кредитного забезпечення вітчизняних сільськогосподарських товаровиробників необхідно: забез- печити ресурсну підтримку агрооріснтованих банків, що, як і раніше, активно беруть участь у кредитуванні сільського господарства; змінити порядок субсидування відсоткових ставок за кредит для дрібних сільськогосподарських позичальників, для яких цей шлях фінансової підтримки, в більшості випадків, стає недоступним через значні витрати часу та коштів на збір та оформлення необхідних документів.

Таким чином, інструменти державної підтримки у формі пільгового кредитування окремих видів господарюючих суб'єктів сільського господарства через кредитні організації, субсидії на відшкодування витрат сільгоспвиробників на погашення кредитів, підтримка та розвиток сільськогосподарської кредитної кооперації повинні здійснюватися одночасно з розвитком банківського кредитування суб'єктів сільського господарства та небанківського кредитування у формі кредитної кооперації самих суб'єктів сільського господарства. Особливу увагу слід приділити розвитку сільських територій, що передбачає створення умов для їхнього соціально-економічного розвитку з метою підвищення якості життя сільських жителів і створення умов для підприємництва на селі.

\section{Список літератури:}

1. Koester, Ulrich; von Cramon-Taubadel, Stephan (2019) Besonderheiten der landwirtschaftlichen Kreditmärkte, Discussion Paper, No. 185, Leibniz Institute of Agricultural Development in Transition Economies (IAMO), Halle (Saale).

2. Дем'яненко М.Я., Саблук П.Т., Скупий В.М. Державна політика фінансової підтримки розвитку аграрного сектору АПК : монографія. Київ : ННЦ ІАЕ, 2011. 372 с.

3. Державна підтримка АПК-2020. Кредити, тваринництво, фермерство, техніка, садівництво. Агрополіт : веб-сайт. URL: https://agropolit.com/spetsproekty/694-derjpidtrimka-agrariyiv-2020-krediti-tvarinnitstvo-fermerstvo-tehnika-sadivnitstvo (дата звернення: 15.05.2020).

4. Державна підтримка сільського господарства: урядові програми 2018. URL: http://dotacii.minagro.gov.ua/ua (дата звернення: 27.05.2020).

5. Думанська І.О. Банківське кредитування в системі фінансового забезпечення інноваційного процесу АПК. Фінансово-кредитна діяльність: проблеми теорії та практики. 2018. Вип. 2. С. 17-26.

6. Звіт про фінансову стабільність. НБУ. URL: https://bank.gov.ua/admin uploads/article/FSR 2019-H2.pdf?v=4 (дата звернення: 12.06.2020).

7. Інформація щодо державної фінансової підтримки суб'єктів господарювання АПК по Україні у 2018 році. URL: http://minagro.gov.ua/uk/support apk (дата звернення: 04.05.2020).

8. Корнійчук Г.В. Фінансові ресурси як елемент фінансового потенціалу агроформувань. Інвестиції: практика та досвід. 2017. № 8. С. 44-45.

9. Лупенко Ю.О. Банківське кредитування аграрного сектору економіки. Економічний вісник НТУУ «КПI». 2019. C. 196-207.

10. Маслак Н. Банки та АПК України: співпраця триває. Пропозищзія. 2017. № 5. С. 154-160.

11. Непочатенко О.О., Бечко П.К., Корнега А.О. Кредитні ризики в системі банківського кредитування аграріїв. Збірник наукових працьь Уманського національного університету садівництва. 2016. № 88(2). С. 7-20.

12. Опитування та умови банківського кредитування. Офіційний веб-портал НБУ. URL: https://bank.gov.ua/admin uploads/article/BLS_Q2-2020.pdf?v=4 (дата звернення: 02.06.2020).

13. Програми підтримки АПК у 2020 році. Khoda.gov.ua : веб-сайт. URL: https://khoda.gov.ua/programip\%D1\%96dtrimki-apk-u-2020-roc\%D1\%96 (дата звернення: 21.05.2020).

14. Салогуб I.I. Кредитування аграрного виробництва: особливості, проблеми, напрями розвитку. Підприємництво та інновачії. Вип. 9. 2019. С. 49-53.

15. Сільське господарство України. Статистичний збірник 2018. Київ, 2019. 235 с.

16. Статистика фінансових ринків: Національний Банк України. URL: https://www.bank.gov.ua (дата звернення: 05.05.2020).

17. Сьомченков О.А. Фондовий ринок у фінансовому забезпеченні агропромислового виробництва : автореф. дис. на здобуття наук. ступеня д-ра екон. наук. Київ, 2017. 39 с.

18. Уніят Л. Розвиток системи державного регулювання та підтримки бізнесу на інноваційній основі у підприємствах АПК. Економічний аналіз. 2019. № 1. С. 44-54. 
19. Уряд розширив напрями держпідтримки аграріїв - деталі. Agropolit.com : веб-сайт: URL: https://agropolit.com/ news/16183-uryad-rozshiriv-napryamki-derjpidtrimki-agrariyiv--detali (дата звернення: 10.05.2020).

20. Фінансування 3 Державного бюджету. Інформаційно-аналітичний портал АПК України: веб-сайт. URL: https://agro.me.gov.ua/ua/napryamki/finansova-politika/finansuvannya-z-derzhavnogo-byudzhetu (дата звернення: 02.06.2020).

\section{References:}

1. Koester, Ulrich; von Cramon-Taubadel, Stephan (2019) Besonderheiten der landwirtschaftlichen Kreditmärkte, Discussion Paper, No. 185, Leibniz Institute of Agricultural Development in Transition Economies (IAMO), Halle (Saale).

2. Demianenko M.Ya., Sabluk P.T., Skupyi V.M. (2011) Derzhavna polityka finansovoi pidtrymky rozvytku ahrarnoho sektoru APK [State policy of financial support for the development of the agricultural sector of the agro-industrial complex]. Kyjiv: NKCz IAE. (in Ukrainian)

3. Derzhavna pidtrymka APK-2020. Kredyty, tvarynnytstvo, fermerstvo, tekhnika, sadivnytstvo (2020) [State support of APC-2020. Loans, animal husbandry, farming, machinery, horticulture]. Agropolit. Available at: https://agropolit.com/spetsproekty/694-derjpidtrimka-agrariyiv-2020-krediti-tvarinnitstvo-fermerstvo-tehnika-sadivnitstvo (accessed 15 May 2020).

4. Derzhavna pidtrymka silskoho hospodarstva: uriadovi prohramy 2018 [State support for agriculture: government programs 2018]. Available at: http://dotacii.minagro.gov.ua/ua (accessed 27 May 2020).

5. Dumanska I.O. (2018) Bankivske kredytuvannia v systemi finansovoho zabezpechennia innovatsiinoho protsesu APK [Bank lending in the system of financial support of the innovation process of agro-industrial complex]. Financial and credit activities: problems of theory and practice, vol. 2, pp. 17-26.

6. Zvit pro finansovu stabilnist (2019). NBU. Available at: https://bank.gov.ua/admin_uploads/article/FSR_2019-H2. pdf? $=4$ (accessed 12 June 2020).

7. Informatsiia shchodo derzhavnoi finansovoi pidtrymky subiektiv hospodariuvannia APK po Ukraini u 2018 rotsi (2018) [Information on the state financial support of agribusiness entities in Ukraine in 2018]. Available at: http://minagro. gov.ua/uk/support_apk (accessed 04 May 2020).

8. Korniichuk H.V. (2017) Finansovi resursy yak element finansovoho potentsialu ahroformuvan [Financial resources as an element of the financial potential of agricultural formations]. Investments: practice and experience, vol. 8, pp. 44-45.

9. Lupenko Yu.O. (2019) Bankivske kredytuvannia ahrarnoho sektoru ekonomiky [Bank lending to the agricultural sector of the economy]. Economic Bulletin of NTUU «KPI», pp. 196-207.

10. Maslak N. (2017) Banky ta APK Ukrainy: spivpratsia tryvaie [Banks and agro-industrial complex of Ukraine: cooperation continues]. Offer, vol. 5, pp. 154-160.

11. Nepochatenko O.O., Bechko P.K., Korneha A.O. (2016) Kredytni ryzyky v systemi bankivskoho kredytuvannia ahrariiv [Credit risks in the system of bank lending to farmers]. Zbirnyk naukovykh prats Umanskoho natsionalnoho universytetu sadivnytstva, Uman, vol. 88(2), pp. 7-20.

12. Opytuvannia ta umovy bankivskoho kredytuvannia (2020) [Surveys and terms of bank lending]. NBU. Available at: https://bank.gov.ua/admin_uploads/article/BLS_Q2-2020.pdf?v=4 (accessed 02 June 2020).

13. Prohramy pidtrymky APK u 2020 rotsi (2020) [AIC support programs in 2020]. Khoda.gov.ua. Available at: https://khoda.gov.ua/programi-p\%D1\%96dtrimki-apk-u-2020-roc\%D1\%96 (accessed 02 May 2020).

14. Salohub I.I. (2019) Kredytuvannia ahrarnoho vyrobnytstva: osoblyvosti, problemy, napriamy rozvytku [Lending for agricultural production: features, problems, directions of development]. Entrepreneurship and innovation, vol. 9, pp. $49-53$.

15. Derzhavna sluzhba statystyky Ukrainy (2018) Silske hospodarstvo Ukrainy [Agriculture of Ukraine], Kyiv.

16. Statystyka finansovykh rynkiv (2020) [Financial markets statistics]. NBU. Available at: https://www.bank.gov.ua (accessed 05 May 2020).

17. Somchenkov O.A. (2017) Fondovyi rynok u finansovomu zabezpechenni ahropromyslovoho vyrobnytstva [Stock market in the financial support of agro-industrial production] ( $\mathrm{PhD}$ Thesis), Kiev.

18. Uniiat L. Rozvytok systemy derzhavnoho rehuliuvannia ta pidtrymky biznesu na innovatsiinii osnovi u pidpryiemstvakh APK [Development of the system of state regulation and business support on an innovative basis in agro-industrial enterprises]. Economic analysis, vol. 1, pp. 44-54.

19. Uriad rozshyryv napriamy derzhpidtrymky ahrariiv - detali (2020) [The government has expanded the areas of state support for farmers - details]. Available at: https://agropolit.com/news/16183-uryad-rozshiriv-napryamki-derjpidtrimki-agrariyiv--detali (accessed 10 May 2020).

20. Finansuvannia z Derzhavnoho biudzhetu (2020) [Financing from the State budget]. Information and analytical portal of the AIC of Ukraine. Available at: https://agro.me.gov.ua/ua/napryamki/finansova-politika/finansuvannya-z-derzhavnogo-byudzhetu (accessed 02 June 2020). 


\section{КРЕДИТНЫЕ АСПЕКТЫ ГОСУДАРСТВЕННОЙ ПОДДЕРЖКИ СЕЛЬСКОХОЗЯЙСТВЕННОГО ПРОИЗВОДСТВА УКРАИНЫ}

Сельскохозяйственное производство является важной отраслью экономики Украины, от степени развития которой зависит благосостояние населения страны и ее продовольственная безопасность. И сейчас в состав механизма государственной поддержки развития сельскохозяйственного производства отдельной программой входит частичная компенсация проиентной ставки по привлеченным в национальной валюте банковским кредитам. Проблематика исследования обусловлена наличием ограниченного опыта применения данного механизма. В представленной статье анализируются показатели объемов кредитования и предоставленных субсидий уполномоченными банками, участвуюшими в реализации государственной программы льготного кредитования. В ходе исследования обозначены основные проблемы реализачии механизма льготного кредитования сельскохозяйственного производства Украины и положительные итоги его совериенствования. Сделан вывод о высокой потребности хозяйствуюших субъектов сельского хозяйства в кредитных ресурсах и необходимости их поддержки со стороны государства.

Ключевые слова: сельскохозяйственное производство, банковское кредитование, прочентная ставка, государственная поддержка, эффективность.

\section{CREDIT ASPECTS OF STATE SUPPORT FOR AGRICULTURAL PRODUCTION OF UKRAINE}

Agricultural production is an extremely important sector of the Ukrainian economy. Currently, within the state support for the development of agricultural production in the country, there is a mechanism for partial compensation of interest rates on bank loans attracted in the national currency. The main problems of the study are due to the limited experience in the application of this mechanism in the country and, accordingly, the low adaptability of credit institutions to its implementation in accordance with the specifics of agricultural enterprises. The system of lending to agricultural production has a number of important features that lead to a decrease in effective demand and timely supply of financial resources. Agricultural lending in the conditions of the market mechanism is an active tool of state regulation of agricultural production, which ensures the formation of an efficient market system, as well as the use offactors of economic growth. As market relations develop in the country, the role of the state in direct financing may be reduced, provided that the role of the state as a guarantor of stimulating market financial institutions to participate in the process of financial and credit support of this industry. The article analyzes the indicators of credit activity, lending volumes and subsidies provided to authorized banks participating in the implementation of the mechanism of preferential lending. The research identified both the main problems of the implementation of the mechanism of preferential lending to the agricultural sector of the country, and the positive consequences of its improvement. Based on the analysis, the conclusion will be the high need of economic entities of agricultural production in credit resources and the need for their support by the state. In order to form a reliable and affordable system of financial and credit support for domestic agricultural producers, it is necessary to provide resource support to agro-oriented banks, which are still actively involved in lending to agriculture; change the procedure for subsidizing interest rates on loans for small agricultural borrowers, for whom this way of financial support, in most cases, becomes unavailable due to the significant cost of time and money to collect and process the necessary documents.

Key words: agricultural production, bank lending, interest rate, state support, efficiency. 